\title{
外傷性クモ膜下出血の臨床的検討
}

\author{
滝沢 责昭·松本 皓·佐藤 昇掛·佐能 昭·高橋 一則·大田 浩右
}

\section{Traumatic Subarachnoid Hemorrhage}

\author{
Takaaki Takizawa, Akira Matsumoto, Shoju Sato, Akira Sano, \\ Kazunori TAKAHASHI and Kousuke OHTA
}

Department of Neurosurgery, Ohta Hospital, Fukuyama, Hiroshima

\begin{abstract}
One hundred and ninety-seven cases with closed head injury were cncountered from April 1980 to December 1982. Computerized tomography (CT) scans of these cases showed traumatic intracranial organic lesions such as epidural hematoma, subdural hematoma, and brain contusion. Among these cases, $23(11.7 \%)$ had only subarachnoid hemorrhage on CT scan, which was performed within several hours of the injury. The five adult patients whose CT scans showed massive subarachnoid hemorrhage in the basal, prepontine, and perimesencephalic cisterns had severe brain-stem damage, and their outcomes were poor. Four adult patients whose CT scans showed moderate subarachnoid hemorrhage in the basal cistern had disturbances of consciousness without brain-stem dysfunction, and their outcomes were fair. Impact sites of injury in the seven of 10 patients with small subarachnoid hemorrhage localized in the ambient and/or quadrigeminal cisterns, were face or forehead. This suggested that subarachnoid hemorrhage was produced by shear strain at the craniocervical junction due to hyperextension of the head or by impact at the tentorial notch. All of these cases recovered, but three of the 10 patients had peripheral oculomotor palsy. The four children had relatively good outcomes compared with the adult cases. The outcomes of the 23 cases as measurcd 3 months after injury according to the Glasgow Outcome Scale were as follows; good recovery 13, moderate disability 4, severe disability 1, vegetative 1, and dead 4.
\end{abstract}

Key words: traumatic subarachnoid hemorrhage, computerized tomography

\section{I はじめに}

CT スキャンの普及に伴い，頭蓋内疾患の診断は飛躍的 に向上した，頭部外傷症例の診断・治療に捛いてもその利 用価値は大きく，頭部外傷のさまざまな病態もしだいに明 らかにされつつある. 外傷性クモ膜下出血もその一つで, 受傷早期から診断可能となったばかりでなく，その程度ま でも把握できるようになった。従来外傷性クモ膜下出扗は 一次性脳幹部損傷の存在を亦唆する CT 所見の一つとして 考えられてきたにすぎず，その臨床的検討を試みた報告は
ほとんどみられない，しかし，一口に外傷性クモ膜下出血 といってもその出血の部位と程度はさまざまで, 必ずしも 予後不良例ばかりではない，そこで今回我々は，これまで に経験した CT 上診断された外傷性クモ膜下出血症例を取 り上げ，発症頻度，CT 所見とその経時的变化，病態発現 機序，予後について検討を行う機会在得たので，若十の文 献的考察を加え報告する。

\section{II 対象および方法}

1980年4月より1982年12月までに当院に入院した頭部外

\footnotetext{
福山大田病院脳神経外科

Address reprint requests to: T. Takizawa, M. D., Department of Neurosurgery, Ohta Hospital, 3-6-28 Okinogami-cho, Fukuyama, Hiroshima 720.

受稿 1983年7 月11月受理 1984年2月21日
} 
傷怔例の5ち，CTスキャン(東芝60-A，島津 SCT$100 \mathrm{~N})$ 亿て頭蓋骨,骨折以外の器質的頭蓋内病变复認好た のは197例であった。このうちCT スキャントクモ膜下胑 に高吸収域を認めたものは49症例(25\%)で，脎内出血ある いは血腫を伴った脳挫傷や硬膜外血腫, 硬膜下血腫を台垪 した26例を除外した残り23拝例 $(11.7 \%)$ を刘象とした。す

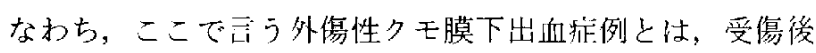
数時間以内に般入され，ただちに施行されたCTスキャン 検查にてクモ膜下腔に高吸収域志諗好るも脳実質内には大 した器筫的病変を認めがたかった症例である。今回は，こ れら23症例のCT 所見, 初診時神経学的所見ならびに予徭 について検討した。

CT スキャン上高吸收域㤎めたクモ膜下整老便宜トタ モ膜下出遍の壮血部位として prepontine cistern interpeduncular cistern, ambient cistern quadrigeminal cistern, basal (parasellar) cistern, Sylvian fissure O4 群に分け,
$\mathrm{CT}$ 上の高吸収域の程度により出血量を多量, 中等量, 少 量と区別した。初診時の意識レベルの判定には Glasgow Coma Scale (GCS) $)^{10}$ 在使用し，予後の判定は受傷後 3 カ月以上経過した時点で Glasgow Outcome Scale ${ }^{10}$ 亿従い 行った。な拉，一部の泟例では日本光電 Neuropack 童用 い㯖性脳幹反応を記録した。

\section{III 結 果}

\section{1. クモ膜下出血の程度と予後}

全 23 症例の概要は Table 1 に示寸通りである。〈将例 1 〜19〉は成人例，〈拝例20２3〉は小児例であり，CT所見 と臨休所見において若十の美異が認められた。クモ膜下出 血の庄がりとしては，出血が比較的広範围のクモ膜下腔に 認められた症例(〈症例 $\mathbf{1} \sim 8,21 ， 23\rangle)$ と ambient cistern や quadrigeminal cistern に限局した症例（〈症例 9，10， 14２0,22〉）とに一大別され, basal cistern やSylvian

Table 1 Summary of 23 cases with traumatic subarachnoid hemorrhage ( $\mathrm{SH}$ )

\begin{tabular}{|c|c|c|c|c|c|c|c|c|c|c|c|c|}
\hline \multirow[b]{2}{*}{$\begin{array}{l}\text { Case } \\
\text { No. }\end{array}$} & \multirow[b]{2}{*}{$\begin{array}{l}\text { Age, } \\
\text { Sex }\end{array}$} & \multicolumn{4}{|c|}{ Localization of $\mathrm{SH}^{*}$} & \multicolumn{5}{|c|}{ Neurological findings } & \multirow[b]{2}{*}{$\begin{array}{l}\text { Other } \\
\text { findings }\end{array}$} & \multirow[b]{2}{*}{$\begin{array}{c}\text { Out- } \\
\text { come } e^{* * * *}\end{array}$} \\
\hline & & $\begin{array}{l}\text { Prepontine } \\
\& \text { inter- } \\
\text { peduncular } \\
\text { cisterns }\end{array}$ & $\begin{array}{l}\text { Ambient } \\
\text { \& quadri- } \\
\text { geminal } \\
\text { cisterns }\end{array}$ & $\begin{array}{c}\text { Basal } \\
\text { cistern }\end{array}$ & $\begin{array}{l}\text { Sylvian } \\
\text { fissure }\end{array}$ & $\begin{array}{l}\text { Conscious- } \\
\text { ness** }\end{array}$ & $\begin{array}{l}\text { Respi- } \\
\text { ratory } \\
\text { distur- } \\
\text { bance }\end{array}$ & $\begin{array}{l}\text { Doll's } \\
\text { eye } \\
\text { pheno- } \\
\text { menon }\end{array}$ & $\begin{array}{l}\text { Aniso- } \\
\text { coria }\end{array}$ & $\begin{array}{c}\text { Abdu- } \\
\text { cens } \\
\text { palsy }\end{array}$ & & \\
\hline 1 & $19, \mathrm{~F}$ & HH & H & +4 & & 3 & + & + & + & & $\mathrm{BF}$ & $D$ \\
\hline 2 & $20, \mathrm{M}$ & H & $+H$ & ++ & & 4 & + & + & + & & $\mathrm{BF}, \mathrm{PN}$ & $\mathrm{D}$ \\
\hline 3 & $18, \mathrm{M}$ & $H$ & $H$ & + & & 4 & + & + & & & IVH & $\mathrm{D}$ \\
\hline 4 & $22, M$ & $H$ & + & & + & 4 & + & + & + & & IVH & $\mathrm{V}$ \\
\hline 5 & $20, \mathrm{~F}$ & H & + & H & & 4 & + & & + & & IVH & SD \\
\hline 6 & $61, \mathrm{M}$ & H & & H & $H$ & 6 & & & & & $\mathrm{SF}, \mathrm{BF}, \mathrm{IVH}, \mathrm{HY}$ & $\mathrm{D}$ \\
\hline 7 & $45, \mathrm{M}$ & H & & + & $H$ & 6 & & & & + & BF, IVH, HY & MD \\
\hline 8 & $62, \mathrm{M}$ & + & & + & + & 6 & & & & & & $\mathrm{MD}$ \\
\hline 9 & $63, \mathrm{M}$ & & $H$ & & & 6 & & & + & & & MD \\
\hline 10 & $54, \mathrm{~F}$ & & + & & & 7 & & & & & & $G$ \\
\hline 11 & $71, \mathbf{F}$ & & & & + & 10 & & & & & $\mathrm{SF}$ & $\mathrm{G}$ \\
\hline 12 & $73, \mathbf{F}$ & & & H & & 10 & & & & & & $\mathrm{G}$ \\
\hline 13 & $45, \mathrm{M}$ & & & + & + & 13 & & & & & $\mathrm{BF}$ & $\mathrm{G}$ \\
\hline 14 & $19, \mathbf{M}$ & & + & & & 13 & & & & & & $\mathrm{G}$ \\
\hline 15 & $45, \mathrm{M}$ & & + & & + & 14 & & & + & & & $\mathrm{G}$ \\
\hline 16 & $56, \mathrm{~F}$ & & + & & & 14 & & & + & & SF & $\mathrm{G}$ \\
\hline 17 & $46, F$ & & + & & & 15 & & & + & & & $\mathrm{G}$ \\
\hline 18 & $43, \mathrm{M}$ & & + & & & 15 & & & & & & $G$ \\
\hline 19 & $46, \mathrm{~F}$ & & + & & & 15 & & & & & & $G$ \\
\hline 20 & $3, \mathbf{M}$ & & + & + & + & 4 & + & & + & & & MD \\
\hline 21 & $6, \mathbf{M}$ & $H$ & $H$ & H & & 10 & & & & + & $\mathrm{SF}, \mathrm{BF}, \mathrm{HY}$ & $G$ \\
\hline 22 & $2, \mathbf{M}$ & tr & + & & & 10 & & & & & $\mathrm{SF}, \mathrm{IVH}, \mathrm{HY}$ & $\mathrm{G}$ \\
\hline 23 & $1, \mathrm{M}$ & $H$ & $H$ & HH & & 10 & & & & & SF & $\mathrm{G}$ \\
\hline
\end{tabular}


fissure のみに限局した怔例(〈症例11〜13〉)は少なかった。 これら症例の予後は，当然のことながら一般にクモ膜下出 血の広がりが広籁网である任ど不良であった。しかし小照 例では成人例と晎なり，広洲なクモ膜下出血にもかか力ら ず予後は比較的主好な傾向が認好られた。

\section{2. 初診時神経学的所見とクモ膜下出血の程度および予後} 〈痛例 $1 \sim 5$ 〉に抢いては衫診時の GCS は 4 以下で， Cheyne-Stokes 呼吸や過时吸などの垀吸異労，人形の眼現

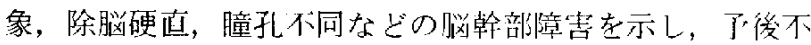
良であった。これらの症例ではタモ膜下出血も庄範用に液

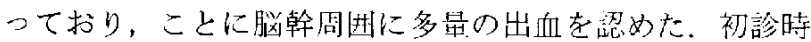

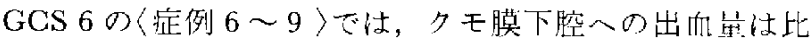

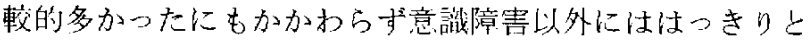
した脳幹部障害老示寸局所異常所見は涊められなかーた。 これら4症例では 1 例が荤発性䑈内血腫孛生じ死亡した が，他の 3 例はいずれも若十の付添介助老要するも有意義 な日常牛活を送れるほどに回復している。しかし5ち 1 例

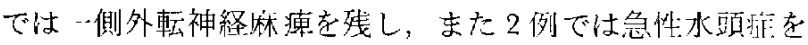
合併し一時的に脳棎ドレナージを施行した経過がある。 〈怔例10１9〉では初診時 GCS 梳 7 以上であり，3例に术

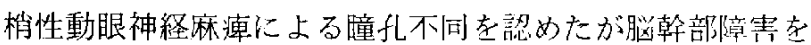

Table 2 Summary of 10 cases with subarachnoid hemorrhage (SH) localized in ambient and/or quadrigeminal cisterns

\begin{tabular}{|c|c|c|c|c|c|c|c|}
\hline \multirow{2}{*}{$\begin{array}{l}\text { Case } \\
\text { No. }\end{array}$} & \multirow{2}{*}{$\begin{array}{c}\text { Side } \\
\text { of } \\
\mathrm{SH}\end{array}$} & \multirow{2}{*}{$\begin{array}{l}\text { Impact } \\
\text { site }\end{array}$} & \multicolumn{2}{|c|}{$\begin{array}{c}\text { Oculomotor } \\
\text { palsy }\end{array}$} & \multicolumn{2}{|c|}{$\begin{array}{c}\text { Repeated CT on } \\
\text { the } 2 \text { nd day }\end{array}$} & \multirow{2}{*}{$A B R$} \\
\hline & & & Side & Lesion & $\begin{array}{c}\text { Plain } \\
\text { CT } \\
\text { density }\end{array}$ & $\begin{array}{c}\text { Enhance- } \\
\text { ment }\end{array}$ & \\
\hline 9 & bil. & face & lt. & central & low & + & normal \\
\hline 10 & rt. & unknown & & & low & & \\
\hline 14 & rt. & $\begin{array}{l}\text { lt. fron- } \\
\text { tal }\end{array}$ & & & low & - & \\
\hline 15 & lt. & $\begin{array}{l}\text { rt. fron- } \\
\text { tal }\end{array}$ & rt. & $\begin{array}{l}\text { peri- } \\
\text { pheral }\end{array}$ & low & - & \\
\hline 16 & rt. & unknown & rt. & $\begin{array}{l}\text { peri- } \\
\text { pheral }\end{array}$ & high & & \\
\hline 17 & lt. & $\begin{array}{l}\text { rt. fron- } \\
\text { tal }\end{array}$ & lt. & $\begin{array}{l}\text { peri- } \\
\text { pheral }\end{array}$ & high & - & normal \\
\hline 18 & rt. & $\begin{array}{l}\text { lt. fron- } \\
\text { tal }\end{array}$ & & & low & + & \\
\hline 19 & rt. & $\begin{array}{l}\text { lt. fron- } \\
\text { tal }\end{array}$ & & & low & + & normal \\
\hline 20 & lt. & jaw & $\mathrm{rt}$ & central & high & & $\begin{array}{c}\text { delay of } \\
\text { lt. } 5 \text { th } \\
\text { wave }\end{array}$ \\
\hline 22 & bil. & $\begin{array}{c}\text { occipi- } \\
\text { tal }\end{array}$ & & & low & & \\
\hline
\end{tabular}

CT indicates computerized tomography; ABR, auditory brain stem response.
ホす寸所見は諰められず，す心て子啳は良好であった。これ らの拝例ではCT上のタモ膜ド出向も译く, 一側の ambient cistern, quadrigcminal cistern, Sylvian fissureなどに 限台性の出血を涊めた程度であった。

小览例の〈症例20〜23〉では，クモ膜下腔に多量の出血を 認めたにもかか的ず脳幹部障茜は 1 例にみられたのみで あった。初診時の GCSを3例では10で女り，GCS 4 で女

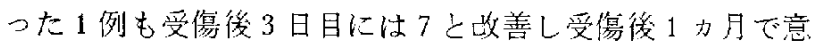
識清明上なった。これら4症例山2 例で水頭症を合併し兴

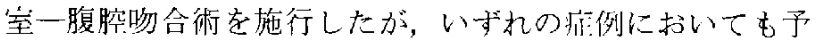
㣪は良好であった。

\section{3. 限局性クモ膜下出血と受傷（打缮）部位}

対象症例 $の$ 約半数を、兄るる, クモ膜下出血が ambient cisternやquadrigeminal cistern のみに限局していた拝例を まこめたのが Table 2 である。忺血を雨側性にみたものが 2 例，右側のみが 5 例，左側のみが 3 例であった。打撲部 位の判明した 8 例では，顔泊女るいは前䫓部老打撲したも のが 7 例，後頭部打撲が 1 例であった。〈症例15〜17〉ては 末梢性動眼祐経麻痺を合併しており，亏ち2例では動眼神 経麻痺側と出血側とが一致していた。Ambient cisternや quadrigeminal cisternに限局した出向はその70\%(10例中 7 例)が受傷翌日のCTですでに認められなくなっていたが， 造影剂を用した enhanced CTで受傷当日の出血部位に一

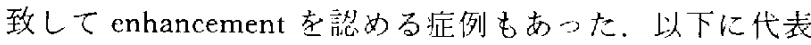
的な詑例を提示する。

\section{<症例 $2>20$ 个, 男性.}

乗用車運転中電柱に激突し前竨部を打撲した。初診時 中枢性過呼吸，除脳硬画，左噇孔散大它認め，脸幹部損傷の 存在が考えられた．CTでは全夕モ膜下脖に人虽の出向を

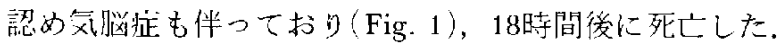
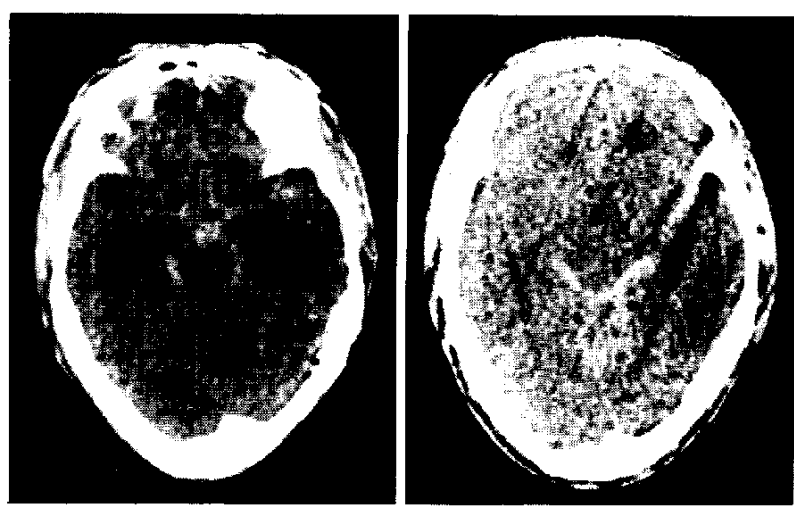

Fig. 1 Computerized tomography (CT) scans of Case 2. Massive subarachnoid hemorrhage is observed in the basal and perimesencephalic cisterns. 

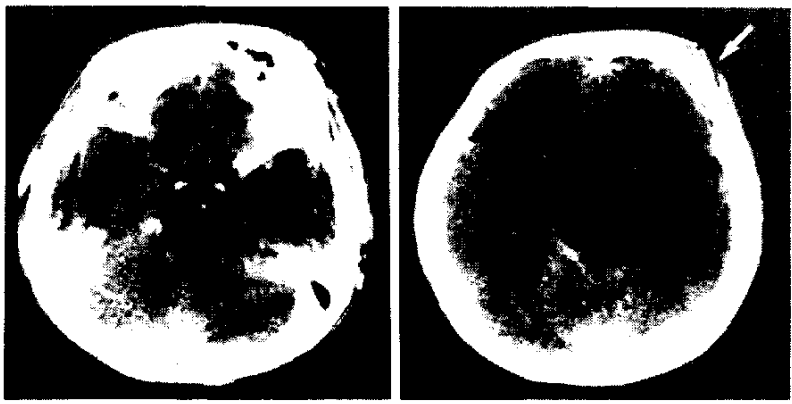

Fig. 2 CT scans of Case 17. Small hemorrhage is shown in the left ambient cistern. Inpact site is suggested by the subcutaneous injury seen on the right frontal area (arrow).

<症例17>46才, 女性

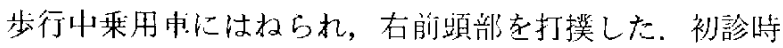
意識清明で，末梢性左動眼神経炑瘦を認好る以外注神経学 的異常を認めなかった．CTでは左 ambient cisternに小出 血を認めた(Fig. 2) が聴性脳幹反心で汢異常は認められ ず，動眼神経麻愺は約 3 カ月でほぼ改善した。

<症例18> 43 才, 男性

乗用車を運転中，衝突事故にて左前頭部定打撲した。初 診時上り神経学的脱落症. 状仗認められなかった。来院時の CT で在 quadrigeminal cistern に小出血を認めたが翌日の CT では出血は消失し， enhanced CTにて同部が enhance された(Fig. 3)。本例はその後順調な経過を辿り退院し た。

<症例20> 3 才, 男児

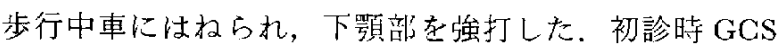
4 , 除脳硬血, 呼吸不全, 瞕孔不同(右>左) 認为, CT
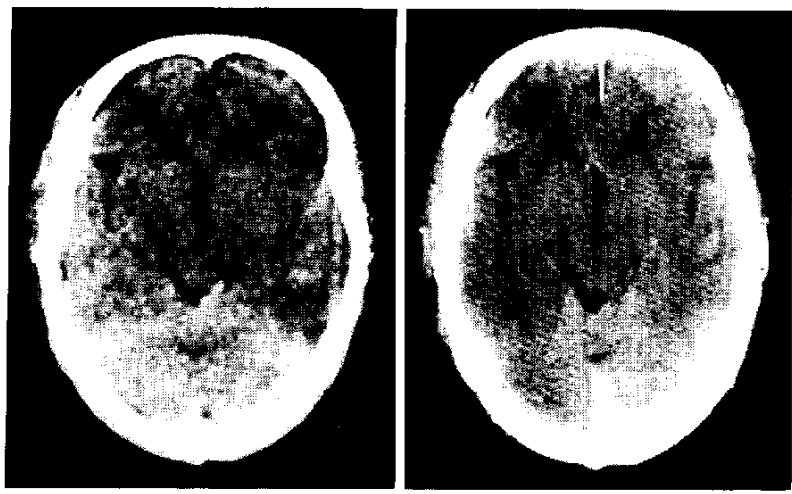

Fig. 3 CT scans of Case 18. left: Plain CT scan shows a small hemorrhage in the right side of quadrigeminal cistern on the day of injury. right: On the next day, almost the same part is enhanced by contrast material.
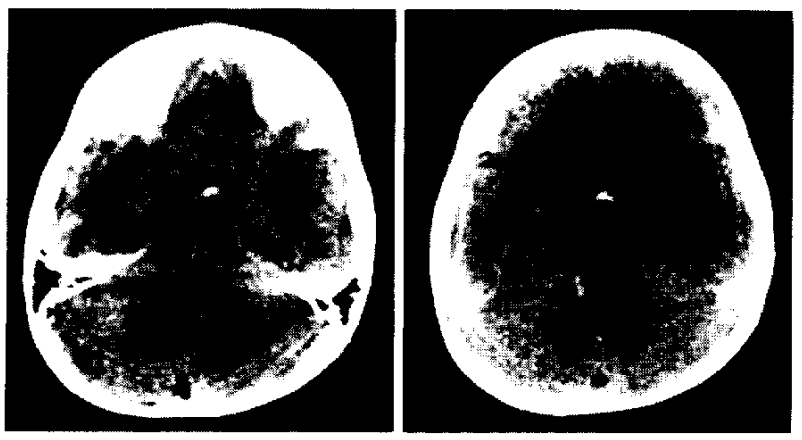

Fig. 4 CT scans of Case 20. Small hemorrhages are observed both in the basal and quadrigeminal cisterns.
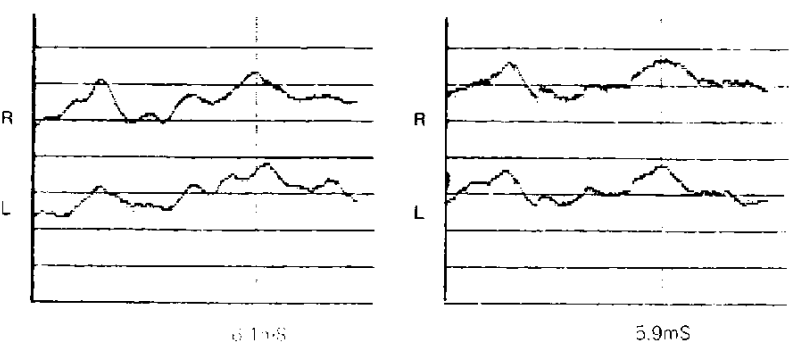

Fig. 5 Auditory brain-stem responses of Case 20. The latency of the fifth wave on the left side is delayed on admission (left), but has returned to normal one month after injury (right).

にて庄 quadrigeminal cistern, basal cistern, 左 Sylvian fissureに小出血老認めた(Fig. 4)。受傷徯 3 日目上り GCS 7 となったが，聴性脳幹反応では左第 V 相の潜時の 延長があり，脳幹障害がホ唆された(Fig. 5)。受傷㣭10日 目頃より意識の改善を認め, 聴性脸幹反忘む正常化した。 受傷媵 3 力月では補装具にて歩行可能で, 知能もほぼ止常 に东で回復している。

\section{IV 考察}

従来, 外傷性クモ膜下出血柱重症顽部外傷の剖㛟時にし ばしば随伴する病埋所見として取り上げられてきた その後 CT スキャンの開発, 普及に上り受傷早期からその 診断が容易となったが，単に脳幹部損傷の存在を示哤する CT 所見の一つ上して考えられてきた。このため，受傷後 数時閒以内のCT スキャンにて診断された外傷性クモ膜下 出血症例を取り上げ，その臨休的检討を行った報告は案外 少ない11,15,23!。我々はこれまでに CT 上外傷性クモ膜卜出 血のみを認めた23症例を経験しているが，これらには重篤 な脸幹部損傷の存在寸るものからなんら神経脱落泳.状のな いものまでさまざまな程度の症例が含东れている，そこで 


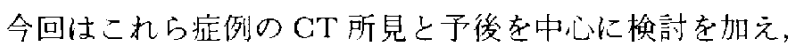
さらにその病態発現に関してむ若下の考察在行った。

まずCT ト脳幹周四のクモ膜下腔に多量の出血を認めた 成人 5 症例（〈证例 $1 \sim 5\rangle$ ) では，臨床神経学的に乎㯖性 脳幹誘発反応に扣いても重篤な脳幹部損傷を示唆する所見 が存在し，いずれも予俊不良であった，したがってこの夕 イプのクモ膜下出血は一次性兴幹損傷の所見の一つと考え られ，小林111の指摘しているように，強力な外力により 生じた shear strainによる兴幹部挫傷に基うくものと推察 さ机る。これは，合併するCT所見として basal cistern,

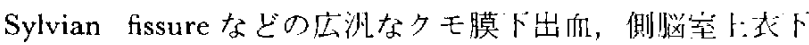
出血, diffuse brain swellingなどが保在することからも動 付けられる。

次にCTト车としてbasal cisternに出向が認められた成 人 4 佂例(〈症例 $6 \sim 8,12\rangle$ )では，初䛦時の神経学的听見 は中等度であったが予㣪は比較的良好であった。これらの 症例に加え，同様に出血老涊必た小児 3 症例(〈症例 $21 \sim$ 23〉)では頭蓋底骨折や後頭骨骨折を伴うことが多く，5ち 4 例に水頙症を，2例に外転神経麻瘦を合併していた。こ れよりこれら症例のクモ膜卜出血は頭蓋底，㣪頭蓋窝で の骨折や硬膜の損傷などに起因するものではなかるうかと 考えられた。

さて，我々がもっとも注目したいの性 CT 上 ambient cistern p qaudrigeminal cistern $み に$ 限局性の出血を認め た10症例(Table 2)である。

まず，神経学的所見および聴吽脳幹誘発反心において山 等度脳幹部損鹪と考えられた 2 拝例(〈症例 $9 ， 20 〉$ )は下顎 あるいは顔面を打撲している. Lindenberg ら $5^{714.17 .22: ~}$

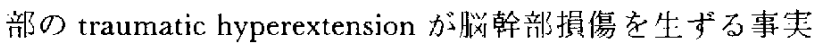
述べておう，Oppenheimer ${ }^{161}$ ，Snoek ら ${ }^{201}$ は craniocervical junction 部での shear strainにより中脳被蓋部に 一次性脳幹部損傷を起こしやすいことを報告している。し たがってこれらの症例は中脸被蓋部の 次吽損傷を有して 扣り，CT上それが近隣のク毛膜下出血として捉学られた と推察している。しかしながらこのタイプの兴幹部損傷 は，前述の兴幹周囲に広沉なクモ膜下出血を呈するものに 比し損㑺程度が軽く，予後も比較的良好であったと考えて いる.

初診時より意識障害が存在しないか軽度であった 8 看例 ではCT上クモ膜下出血は一側の ambient cisternあるい は quadrigeminal cisternに認められるのみで，その5ち打 撲部位の判明している 5 症例(〈征例 14，15，17〜19〉)では すべて出向側と反対側の前側頭部，すなわち脳の中心に対

して対角線上を打撲していることは興味深い，また，これ ら8例中 3 例に・過性の動眼神経麻瘏を合侀していた。
の受傷機転から抦態を推察するに，扢そらく前側頭部打掽 時の衝撃により刘角線上のテント切痕で中脸被蓋表面の脳 組織むしくは小血管が損傷され，同部のクモ膜下出血を生 じたむのではなからうかよ考えている1-3,5,6,8,12,13,18:。 した がって脸幹部損傷としての臨术所見は呈さず，多発する動 眼神経麻痖の存在は一過性の脳幹のひずみや動眼神経の引 き抜き損傷によるものではないかと思われる。

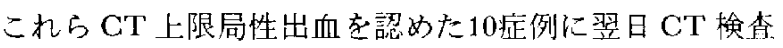
を再度行ってみると，70\%の症例ですでに出血を示す高吸 収域は消裉していた。すなわち, 組織の損傷程度む出血量 も少ないため受傷媛に大した种経脱落应状走さなかった

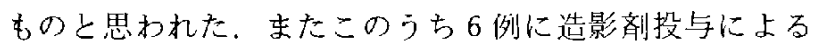
enhanced CT 在行 5 と，3例 $(50 \%)$ に计血部位に一致し た enhancement が認められた。これは兴幹表面の損傷部 や破綻血管加らの造影剂の extravasation, 女るいは Drayer $ら^{1,4,11,19 !}$ の言亏受傷後の hyperperfusion 意味している ものと推察された。

最後に，小少例(〈症例20２3〉)では必ずしも受傷直㣪の CT 所見とは関係なく，成人例上りも予徭は良好であっ た。小児例の予娞の良いこ上はこれまでの䠝部外傷症例全 般の予後に関する解告などですでに周知の事来となってお り，議論をはさむ余地はなかろう。

以上の上5に，受傷後早期にCT スキャンにより骖断さ れた外傷性クモ膜下出血证例にはさまざまなタイプのもの が存在しており，予後も異なっていた。したがって，っモ 膜下出血即一次性脸幹部摃傷の存在ならびに予後不良と考 えるべきではない，これら症例の予後判定には神経学的所 見が基本となるのは当然であるが，CT上の出血部位とそ の程度や脳幹機能に対する牛理学的榆討なども参考とな る。我々は最近聴性脳幹反応による梌討も合せて行ってお り，その有用性を確認している．今姼さらに症例を重权報 告したいと考えている。

\section{$\mathrm{V}$ ま め}

受傷後早期の CT スキャンにて外傷性夕モ膜下出血と診 断された症例は，頭蓋内病変を諗め大急性頭部外傷症例 197例巾23例 $(11.7 \%)$ を占めた。これらの症例の CT 所見， 予㣪を中心に検討を加え，各症例におけるクモ膜下㑑血の 病態発現についても考察した。

1. 3 力月以上経過後の予後としては, good recovery 13 例, moderate disability 4 例, severe disability or vegetative state 2 例, dead 4 例であった。23症例中 4 例の 小児例では，受傷俊早期の CT 所見にかかわらず成人例上 比較して予後は良好であった。

2. CT上広沉なクモ膜下腔, ことに脳幹周囲に多量の 


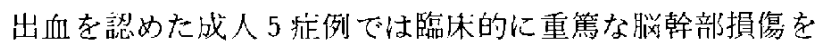
亦し，来院時の GCS は 4 以下で予後む不良であった。

3. CT 上 basal cistern を中心に出血を認加 4 拝例で は，うち3 例で来院時 GCS 6 と意膱障害は強かったが脸 幹部損傷を示寸所見はなく，また水頭症を合併しや寸い僋 向东みるものの予俀は比校的良好であった。

4. CT 上 ambient cistern や quadrigeminal cistern に限 局した小出血を認めた10症例では，顔面や㓩頭部を打撲し た症例が多く予㣪は良好であったが，うち3例に末梢性動 眼神経麻蕙を認めた。

\section{文献}

1）有賀 徽、小林土郎，大榢敏支，西邑信男，本多一義：念 性外傷性気脳症。外倁の CT スキャン一Contrast enhancement を中心に一。脳と神 32: 723730,1980

2) Courville CB: Effects of closed cranial injuries on midbrain and upper pons. Proc Assoc Res Neuro Med Dis 21: 131, 1945

3) Crompton MR: Brainstem lesions due to closed head injury. Lancet 1: 669-673, 1971

4) Drayer BP, Heinz ER, Dujovny M, Wolfson SK Jr, Gur D: Patterns of brain perfusion: Dynamic computed tomography using intravenous contrast enhancement. J Comput Assist Tomogr 3: 633-640, 1979

5) French BN, Dublin AB: The value of computerized tomography in the management of 1000 consecutive head injuries. Surg Neurol 7: 171-183, 1977

6) Gurdjian ES, Lissner HR, Hodgson VR, Patrick LM: Mechanisms of head injury. Clin Neurosurg 12: 112-128, 1966

7) Hardman JM: The pathology of traumatic brain injuries. Adv Neurol 22: 15-50, 1979

8）平山恵造：神経症候学。東京，支光堂，1977, pp 143-144

9) Jennett B, Bond M: Assessment of outcome after severe brain damage. Lancet 1: 480-484, 1975

10) Jennett B, Teasdale G, Braakman R, Minderhoud J, KnillJones R: Predicting outcome in individual patients after severe head injury. Lancet 1: 1031-1034, 1976
11)小林土郎：外傷性一次性脳幹御損傷の CTに上る分類と予 嵝について. Neural Med Chir (Tokyo) 22: 838-848, 1982

12）小林土郎，山川和官，田崎击人，中视省三，西出信男： CT scan で確認し得た外傷性脳幹部損傷の 4 例。神释外傷 2: $5-11,1980$

13) 喿本国久, 河本圭司, 安开信之, 朽名誠, 松村 沿：脳 幹損傷。外傷 6: 313-325, 1975

14) Lindenberg R, Freytay E: Вrainstem lesions characteristic of traumatic hyperextension of the head. Arch Path (Chicago) 90: $509-515,1970$

15）森伸彦，杉浦誠，山本昌炤，今永浩寿，神保実，喜

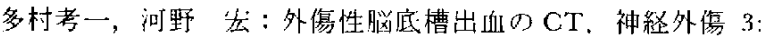
154,1981

16) Oppenheimer DR: Microscopic lesions in the brain following head injury. J Neurol Neurosurg Psychiat 31: 229-306, 1968

17) Patscheider $\mathrm{H}$ : Zur Entstchung von Ringbruchen des Schadelgrandes. Deutsch $Z$ Ges Gerichtl Med 52: 13-21, 1962

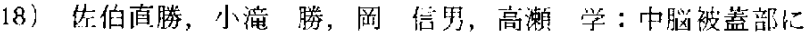
限局した外傷性血腫の1例．脳神外科 9：1193-1197，1981

19) Smith DR, Ducker TB, Kempe LG: Experimental in vivo mirocirculatory dynamics in brain trauma. $J$ Neurosurg 30: 664672,1969

20) Snoek J, Jennett B, Adams JH, Graham DI, Doyle D: Computerized tomography after recent severe head injury in patients without acute intracranial hematoma. $J$ Neurol Neurosurg Psychiatry 42: 215-225, 1979

21) Tatsuno $Y$, Lindenberg $R$ : Basal subarachnoid hernatomas as sole intracranial traumatic lesions. Arch Path (Chicago) 97: 211215,1974

22) Wuermeling von HB, Struck G: Brainstem ruptures in traffic accidents. Beitr Gerichtl Med 23: 297-302, 1965

23) Zimmerman RA, Bilanjuk L'T, Gennarelli T: Computed tomography of shearing injuries of the cerebral while matter. Radiology 127: 393-396, 1978

[別刷請求先：干720広島県福山古沖野上町3-6-28, 福川大田 病院兴神経外科, 滝沢贵昭了 